УДК 78.01+782/785.7+78.07.1

DOI https://doi.org/10.31723/2524-0447-2021-32-2-3

Анатолій Валентинович Носуля

ORCID: 0000-0002-3003-6472

кандидат мистецтвознавства,

в.о. доцента кафедри сольного співу

Одеської національної музичної академії імені А. В. Нежданової

avn.odma@gmail.com

\title{
ВТІЛЕННЯ ОБРАЗУ САРИ БЕРНАР У ОПЕРНІЙ ТВОРЧОСТІ Ю. ГОМЕЛЬСЬКОЇ: ДО ПРОБЛЕМИ АВТОРСЬКОГО СТИЛЮ
}

Мета статmi полягає у вивченні особливостей інтерпретації образу Сари Бернар у опері Ю. Гомельської «Божественна Сара» ("The Divine Sarah") як реалізації актуальних та принципово нових тенденцій у сучасній оперній творчості. Методологія статті базується на принципово оновленому аналітичному підході до оперної творчості періоду кіния XX - початку XXI століть, у тому числі до камерної опери у творчості Ю. Гомельської, на підставі якого стає можлливим виявити характерні особливості композиторського стилістичного комплексу як основи авторського стилю композиторки. Наукова новизна зумовлена тим, що у статті досліджуються характерні типологічні ознаки оперної форми та простежуються аспекти виникнення різних жсанрових модифікацій; відкривається новий аспект вивчення сучасних камерних опер на прикладі опери Ю. Гомельської «Божественна Сара» ("The Divine Sarah"). На основі розгорнутого історіографічного, естетичного та аналітичного музикознавчого підходів характеризуються їі структурно-композиційні ознаки та художньо-образні параметри. Висновки. Аналітичне вивчення музичного тексту «Божественної Сари» Ю. Гомельської дозволяє визначити як одну з провідних ознак ії авторського стилю надзвичайну увагу до художньо-образної деталізованості та яскравої емоційності того дійства, що розгортається на сиені. Пластичне рішення, акторська гра, перебування артистів на відкритому майданчику, надзвичайна важливість театральних ефектів та прийомів, практично повна відсутність декорацій - усе це дозволяє відзначити вдалість авторського визначення твору як опери-сцени. Таким чином, у творчості Юлії Олександрівни Гомельської найбільш помітними стилістичними тенденціями у творах камерного оперного жанру стають граничне скорочення часу звучання, той лаконізм, який дозволяє утримувати увагу слухача на головній ідеї твору - на образі героїні у всій повноті їі переживань та почуттів;

(C) Носуля А. В., 2021 
вибір словесної основи відповідно до загального задуму, включаючи при иьому слово до музично-виразних прийомів, тобто, користуючись ним як частиною музичного цілого.

Ключові слова: опера-сиена, камерна опера, театральність, камернізація, сюжетно-тематичні особливості, індивідуальний авторський стиль.

Nosulia Anatolii Valentynovych, Ph.D. in the History of Art, Acting Assistant Professor at the Department of Solo Singing of the Odessa National A. V. Nezhdanova Academy of Music

The embodiment of the image of Sarah Bernard in the opera works of $Y u$. Gomelskaya: on the problem of the author's style

The purpose of the article is to study the peculiarities of the interpretation of the image of Sarah Bernhardt in the opera by Y. Gomelskaya "The Divine Sarah" as the implementation of current and fundamentally new trends in contemporary opera. The methodology of the article is based on a fundamentally updated analytical approach to the operatic work of the late $X X-$ early $X X I$ centuries, including the chamber opera in the works of Y. Gomelskaya, on the basis of which it becomes possible to identify the characteristic features of the composer's stylistic complex as the basis of the author's style of the composer. The scientific novelty is due to the fact that the article examines the characteristic typological features of the operatic form and aspects of the emergence of various genre modifications; a new aspect of the study of modern chamber operas opens on the example of $Y$. Gomelskaya's opera "The Divine Sarah". On the basis of a detailed historiographic, aesthetic and analytical musicological approaches, its structural and compositional features and artistic-figurative parameters are characterized. Conclusions. Analytical study of the musical text of "The Divine Sarah" by Y. Gomelskaya allows us to define as one of the leading features of her author's style, the extreme attention to the artistic-figurative detail and vivid emotionality of the action unfolding on the stage. A plastic solution, acting, finding artists in an open area, the extreme importance of theatrical effects and techniques, the almost complete absence of scenery - all this allows us to note the success of the author's definition of the work as an opera-scene. Thus, in the work of Yulia Aleksandrovna Gomelskaya, the most noticeable stylistic tendencies in the works of the chamber opera genre are the limiting shortening of the playing time, that laconicism that allows the listener to keep the main idea of the work - the image of the heroine in all the fullness of her experiences and feelings; the choice of the verbal base in accordance with the general concept, including the word for musical expressive techniques, that is, using it as a part of the musical whole.

Key words: opera stage, chamber opera, theatricality, cameralization, plot-thematic features, individual author's style. 
Актуальність. Починаючи з XX століття і дотепер відбуваються значні стильові, музично-мовні зміни у галузі оперного мистецтва, що дозволяє говорити про формування у сучасній композиторській творчості нових уявлень про таку галузь музичного мистецтва. Відхід від усталених протягом століть принципів оперної композиційної рівноваги, що знайшло своє втілення у складній багаточастковій структурі, яка поєднує принципи номерного та наскрізного розвитку, призвів до кризи оперного жанру в XX столітті, до активних пошуків виходу 3 цього стану. Таким чином, дослідження сучасної вітчизняної опери на шляху формування іiі типологічних ознак та виникнення різних жанрових модифікацій є актуальною проблемою для музикознавчого знання. Нині ми можемо говорити, що у сфері оперного мистецтва саме жанрова форма камерної опери стає надзвичайно затребуваною і часом навіть домінуючою. Підтвердженням цього може бути поява в різних країнах фестивалів камерного оперного мистецтва, виникнення спеціальних театрів або малих сцен при оперних театрах, де основою репертуару постановки є саме камерні опери. Причиною цього можна назвати надзвичайну гнучкість і рухливість такої жанрової форми, у якій виявляється можливим вступ у діалог як музичними, так і театрально-сценічними засобами. Отже, на поточний момент можна говорити про період розквіту камерної опери у всіх іiі різновидах, важливість іiі значення як складової частини європейської культурної парадигми в контексті сучасних мистецьких процесів, що, своєю чергою, викликає нагальну потребу музикознавчого осмислення сучасної вітчизняної опери, одним з яскравих прикладів якої є опера Ю. Гомельської «Божественна Сара».

Виклад основного матеріалу. Кінець XX - початок XXI століття стає дуже важливим етапом для розвитку не тільки жанрової форми опери, але й музичного мистецтва загалом, що знаходить своє відображення у авторському стилі видатної одеської композиторки Юлії Олександрівни Гомельської. Як розповідала сама композиторка, для неї однією з показових та необхідних ознак музики XXI століття стає можливість суттєвого переосмислення музично-мовних принципів, що, своєю чергою, дає можливість формування впізнаваного композиторського почерку, вираження індивідуальних рис авторського бачення, авторського стилю. Ю. Гомельська розповідала, що коли вона намагається 3 позиції музикознавця 
розібратися у проблемі авторського стилю композитора, про творчу особистість автора-композитора можна дізнатись саме через характерну манеру музичного самовираження митця 3 його унікальними музично-мовними, «графічними» та семантичними складниками (до яких Ю. Гомельська також відносить почерк, стиль, мову)» [5, с. 190]. Композиторка вказувала, що «коли відбувається період пошуку та вибудовування власної персоніфікованої креативної лабораторії і композитор знаходить себе, свою творчу манеру, то він починає почуватися досить комфортно в «освоєному» просторі, розуміти, що він уже багато... може і вміє» [5, с. 190].

Широко відомо, що кожний музичний твір як об’єкт сприйняття $є$ зафіксованою та окремою художньою структурою, яка складається завдяки відібраним і збалансованим між собою інтонаційним сполученням. Водночас саме у цій зафіксованій художній структурі міститься відображення особистості композитора, а тому такий твір може розглядатися як суб'єкт, процес пізнання якого буде завжди діалогічним.

Як свідчать роботи М. Бахтіна, весь світ можна представити як комплекс діалогічних відносин, що ведуть до зняття об'єктного характеру пізнання, розширюючи і поглиблюючи суб'єктно-об'єктний спосіб бачити світ як діалог, а тому, на його думку, для осмислення будь-якого явища принциповою $€$ загальна установка на діалог. У лінгвістичному аспекті діалогічна теорія дозволяє поглянути на основний «матеріал» цієї науки: вона призводить до того, що слово є спочатку розколотим, розщепленим на кілька голосів, воно ніколи не може бути цілісним і замкнутим у самому собі, навпаки, його розкол наводить до звучання у ньому кількох голосів, тобто воно стає поліфонічним.

Розгляд діалогічних аспектів культури у М. Бахтіна відбувається з двох точок зору: по-перше, з точки зору створення культури особистістю, коли особистість досягає справжнього життя і набуває власної унікальності саме у стані нетотожності до самої себе, вступаючи в подію, тобто діалог 3 «іншим». По-друге, з погляду самої культури, яку дослідник також розглядає як діалогічний процес, де для повного розуміння ії сенсу просто необхідно зробити саму культуру відкритою, незамкненою системою, а iї прояви розглядати у «великому часі» [1]. Відповідно до концепції М. Бахтіна розуміння $€$ принципово незавершеною діяльністю, що завжди 
підпорядковується правилу циркулярності, тобто руху по колах, що постійно розширюються. Повторне повернення від цілого до частини та від частин до цілого змінює та поглиблює розуміння смислу частини, підпорядковуючи ціле постійному розвитку. М. Бахтін розглядає розуміння як охоплення найглибших взаємозв'язків у бутті. Це завжди «думка у світі». Істина завжди «просвічує» крізь твори культури, з'являється нам у одкровеннях та наукових відкриттях, у великих художніх та музичних творах, у філософських працях [1].

Провісник тієї чи іншої ідеї бачить це світло як ціле, у контексті певного світовідчуття, загальної картини світу. Але завжди відкривається лише «краєчок» буття. Зрозуміло, що це відкриття завжди засліплює людину і їй здається, що вона бачить ціле. Але ціле може опинитися лише цілокупністю свідомостей, їх постійним зустрічним рухом як діалогу свідомостей, діалогу культур, діалогу часів. Як вказує у своїй роботі С. Осадча, необхідною умовою існування естетичного стає наявність іiі «діалогічної природи, а така природа $з$ такою ж необхідністю призводить до художньої творчості як до спеціалізованої галузі осмислюючого самопізнання людини, що сприяє створенню особливого - особливого «заселеного», наповненого простору культури - простору художніх артефактів. Такий простір, цілком матеріально-предметний, має свої ідеаційні проєкції - свій простір свідомості» [7, с. 98].

Як вказує В. Бобровський, «художня структура музичного твору як суб'єкт, як активний носій живого духовного змісту - це спектр незліченних можливих смислів, що розкриваються у свідомості, що сприймає (споглядає). Ці можливі смисли об'єднані об'єктивно наявними рамками художньої структури та усвідомлюються диференційовано лише образному сприйняттю кожної особистості. Вона знаходить у цьому спектрі «промінь», що резонує іiі душевному ритму, і розкриває художню ідею, образну систему цього твору відповідно до свого душевного складу» [2, с. 14].

Пізнання художнього (музичного) твору, на думку В. Бобровського, треба розглядати як діалог між твором і особистістю, що сприймає такий твір, підкреслимо, що дослідник вказує на композиторське створення художнього твору як на результат його діалогу (як автора) з реаліями дійсності. Таке пізнання є не одиничним актом, а скоріше, процесом, що принципово не має завершення, який ініціюється автором 
та сприймається завдяки діалогічному включенню слухача. Такий процес неможливо завершити завдяки тому, що «будьяка відповідь на запитання, що ставиться «художнім твором, викликає нове питання, і так до нескінченності, бо вичерпати все багатство ідеї, вкладеної композитором у свій витвір, неможливо. Якщо ж на практиці це виявляється можливим, то сам твір є не глибоким за ідеєю, або слухач обмежує процес пізнання... знайденим змістом» [2, с. 14].

Стиль як вираження закономірностей взаємодії між естетичними принципами та композиторською технікою [3, с. 214] навряд чи викликає таку безпосередню особистісну реакцію. Щоб емоційно сприймати музику, треба передусім ії любити. Міру і ступінь нашої любові до композитора як того складника, що змушує звертатися до музики знову і знову, визначає не сама по собі оцінка його творчості, а специфіка ставлення до його індивідуальності як до «інтонаційного суб'єкта стилю», що досягається «в масштабі всього життя, а не окремого його фрагмента» [6].

Розглядаючи творчий доробок Ю. Гомельської, треба відзначити, що більшість творів композиторки демонструє свою індивідуальну систему організації елементів музичної мови, 3 можливим виділенням як головної їх основи постійного пошуку нових засобів художньої виразності, суттєвого оновлення музично-мовних прийомів та художньо-образних параметрів. Ще однією з найбільш показових рис авторського стилю Ю. Гомельської є тяжіння до вільного трактування усталених принципів та експериментальних пошуків у камерній жанровій сфері. Такий інтерес зумовлений, на наш погляд, прагненням у всій глибині розкрити можливості музичного діалогу. Персоніфікація тембрів особливо виділяє роль просторової перспективи фактури як визначальний характер образної виразності учасників сюжетної канви твору.

Камерна опера «Божественна Cара» (“The Divine Sarah”) у жанровому визначенні самої Ю. Гомельської є оперою-сценою для меццо-сопрано та фортепіано, лібрето М. Ірвіна, прем'єра ii відбулася 2000 року в Лондоні (Великобританія). Жанрове уточнення, дане Юлією Олександрівною, - опера-сцена, що виявляє низку специфічних особливостей цього твору. Насамперед це обмеження дії, що розгортається на сцені, так само як і звучного твору просторово-часовими обмеженнями, з одного боку, з іншого - виникає відчуття максимального зближення 
зі слухацькою аудиторією, максимальне залучення іiі до діалогу. Опера присвячена особистості та сценічному мистецтву великої актриси, чиє високе мистецтво та драматичний талант став причиною появи у неї прізвиська «Божественна Сара». Саме до цього прізвиська, в якому висловлювалися і найбільша повага до таланту, і абсолютне зізнання, відсилає нас Юлія Гомельська назвою свого твору.

Цікаво, що з музичного боку головний конфлікт проявляється у опері за допомогою музичного лейтмотиву долі (сонористичні акордові співзвуччя, що переростають у дзвін) і лейтмотиву натовпу ворогів - репліки пошепки, які вимовляє піаніст, що сидить за роялем. Таким чином, функція піаніста не обмежується інструментальним супроводом опери, він бере постійну активну участь у сценічному дійстві. Вісім епізодів опери розкривають образ великої французької актриси Сари Бернар у різних ракурсах, вони присвячені подіям іiі сценічного та особистого життя.

Багато критиків мистецтва видатної акторки звертали увагу на іiі ставлення саме до процесу інтонування словесного тексту, іноді з практично виконавським вокальним підходом до цього, а іноді, навпаки, відсторонюючись від академічної вокальної манери промови та використовуючи ефект естетичного зниження. Про це писав В. Немирович-Данченко, який дуже критично оцінював іiі гру, зокрема, коли вказував, що «пані Сара Бернар «кричала як торговка». Що ж до скоромовки, співу та малювання, то все це невід'ємні якості французів, і вимагати, щоб пані Сара Бернар позбулася їх на час свого приїзду до Росії - безглуздо. Отже, верх витонченості, «рафінована» гра, присутність деякої нервової сили та строга школа, що цілком задовольняє останнім вимогам французької критики, становлять сутність артистичних заслуг пані Сари Бернар» [4, с. 179-180]. Незважаючи на наявність подібних скептичних зауважень, усе ж таки більшість критиків оцінювали іiі майстерність дуже високо, і практично всі відзначали особливий магнетизм її голосу, називаючи його чарівним, співучим, чудовим і т.д. [4].

Ідея та первісний поштовх у написанні опери про життя Сари Бернар належить відомій англійській співачці Сарі Уолкер (меццо-сопрано), яка і запропонувала Ю. Гомельській та лібретисту М. Ірвіну створити музично-сценічний твір на цю тему. У процесі особистого спілкування автора цієї статті 3 
композиторкою Юлія Олександрівна розповіла про іiї зустріч із М. Ірвіним, яка відбулася у 1997 році. Під час цієї зустрічі було вироблено загальну концепцію лібрето опери, яка грунтувалася насамперед на баченні композиторки та виконавиці - Ю. Гомельської та С. Уолкер.

Надзвичайно цінними є зауваження лібретиста, які він виклав у листі до головної виконавиці Сари Уолкер. Він вказував, що насамперед намагався надати лібрето вигляд портрета, разом із тим не менш важливим він вважав показати Сару Бернар чутливою та вразливою людиною, розкриваючи при цьому важливі віхи іiі акторської кар'єри, і, нарешті, дати можливість розкритися всьому різноманіттю емоційних станів, які переживала актриса на сцені та в житті. У музиці опери відчувається значний вплив стилістичних прийомів: від найсучасніших напрямів - сонористики, алеаторики, пуантилізму - до включення традиційної тонально-гармонічної мови та застосування широковідомих у академічній музичній традиції поліфонічних прийомів. Сонористичні ефекти, гра тембрами стає важливою основою всієї музично-композиційної побудови твору. Відкриває «Божественну Сару» послідовність цілісних барвистих сонористичних блоків, що звучать на педалі фортепіано. Головним матеріалом для побудови звукової тканини стає поєднання сонористичних співзвуч, що сприймається як єдина звукофарба. Щойно помітними виявляються лише межі, крайні обриси «сонорних полів». Згодом ці акорди з'являються на початку п'ятої частини, а потім і у вступі до коду восьмої частини, набуваючи функції лейтмотиву долі.

Авторські уточнюючі ремарки, що вказують на спосіб виконання - «на внутрішній стороні струн фортепіано, у найнижчому регістрі, товстою м'якою калатушкою (подібно до дзвону)», - не залишають сумніву в наявності семантики дзвоновості. Ще одним лейтмотивом, що чинить сильний вплив на формування драматургічної лінії твору, $є$ лейтмотив натовпу недоброзичливців актриси. Цей лейтмотив представлений у вигляді згаданого вище шепоту, який вимовляє піаніст. Він з'являється на початку першої частини опери, у дещо зміненому варіанті в їі ж репризі, а потім - практично у всіх частинах твору, за винятком четвертої та восьмої. Зловісний шепіт спочатку поєднується з вокальним чи інструментальним звучанням, а в п'ятій частині перериває вокальну лінію "Death was an obsession..." («смерть була одержимістю»), 
згодом ця фраза звучить ще двічі в п'ятій частині. У сьомій частині шепіт трансформується у фразу-зітхання "Alas, Poor Sarah...” («На жаль, бідна Сара...»). У вокально-мелодійну партію солістки вплітаються речитативно-декламаційні фрази. I все ж, незважаючи на те, що на початку восьмої частини звучить песимістичний “Does one care?” («Кому тепер це треба?»), завершує оперу катартичне просвітлення "Yet I think, Yet I swear, sometimes the soul took fire, sometimes the God was there...” («Все ще я думаю, все ще я присягаюсь, іноді моя душа спалахувала, іноді Господь був зі мною...»).

Висновки. Аналітичне вивчення музичного тексту «Божественної Сари» Ю. Гомельської дозволяє визначити як одну з провідних ознак її авторського стилю надзвичайну увагу до художньо-образної деталізованості та яскравої емоційності того дійства, що розгортається на сцені. Це підтверджується скрупульозною ретельністю й уважністю до виписування темпових, метричних, агогічних, характерологічних, звуко-колористичних (від подробиць звуковидобування до тонкощів вокального інтонування та говоріння) ремарок. Очевидно, що композиторка намагалася ставити перед виконавцями послідовно роз'яснене завдання, для повного та художньо завершеного здійснення задуманого. 3 боку формотворення в опері $є$ наявними окремі риси рондальності, адже протягом усього твору можна спостерігати включення епізодів з повторюваним матеріалом, що наближає їх за їхнім функційним призначенням до рефрену. Пластичне рішення, акторська гра, перебування артистів на відкритому майданчику, надзвичайна важливість театральних ефектів та прийомів, практично повна відсутність декорацій - усе це дозволяє відзначити вдалість авторського визначення твору як опери-сцени.

Таким чином, у творчості Юлії Олександрівни Гомельської найбільш помітними стилістичними тенденціями у творах камерного оперного жанру стають граничне скорочення часу звучання, той лаконізм, який дозволяє утримувати увагу слухача на головній ідеї твору - на образі героїні у всій повноті їі переживань та почуттів; вибір словесної основи відповідно до загального задуму, включаючи при цьому слово до музичновиразних прийомів, тобто, користуючись ним як частиною музичного цілого. Усі композиційні прийоми, що використовуються композиторкою, підпорядковуються загальній ідеї діалогу, зокрема й на рівні музичної мови. 
У творчості Ю. Гомельської виявляється особлива увага до найдрібніших рухів людської душі, пов'язана з пошуком нової якості звучання музики шляхом запровадження нових, незвичайних колористичних фарб та тембрових ефектів, поєднання різних логік музичного мислення. Водночас у камерних операх та монооперах Ю. Гомельської яскраво виражається загальна спрямованість на створення психологічних портретів, основою яких є прагнення передати складні емоційні стани героя, зафіксувати «кульмінаційні» моменти його переживань.

\section{СПИСОК ЛІТЕРАТУРИ}

1. Бахтин М. К философии поступка. М.М. Бахтин. Работы 1920-х годов. Киев : Наукова думка, 1994. С. 9-68.

2. Бобровский В. Тематизм как фактор музыкального мышления. Москва : Музыка, 1989. Вып 1. 268 с.

3. Бондаренко Т. Про традиції П.І. Чайковського в музичній мові українських композиторів. Чайковський та Україна. Київ : КДК ім. П.І. Чайковського, 1991. С. 197-217.

4. Гительман Л. Сара Бернар. Зарубежное актерское искусство XIX века. Франция. Англия. Италия. США : хрестоматия. СанктПетербург : СПб ГУП, 2002. С. 160-180.

5. Лунина А. Композитор в зеркале современности: в 2-х томах. Киев : Дух і літера, 2015. Т. 1. 504 с.

6. Медушевский В. Человек в зеркале интонационной формы. Советская музыка. 1980. № 9. С. 39-48.

7. Осадчая С. Теоретические аспекты изучения православной певческой традиции: история и современность : монография. Одесса : Астропринт, 2012. 264 с.

\section{REFERENCES}

1. Bakhtin, M. (1994). To the philosophy of action. M.M. Bakhtin. Works of the 1920s. Kiev: Naukova dumka [in Russian].

2. Bobrovsky, V. (1989). Thematism as a factor of musical thinking. Moskva: Music. Issue 1 [in Russian].

3. Bondarenko, T. (1991). On the traditions of P.I. Tchaikovsky in the musical language of Ukrainian composers. Tchaikovsky and Ukraine. Kyiv [in Ukrainian].

4. Gitelman, L. (2002). Sarah Bernard. Foreign acting of the XIX century. France. England. Italy. USA: Reader. Sankt-Peterburg : SPb GUP [in Russian].

5. Lunina, A. (2015). Composer in the mirror of modernity: in 2 volumes. Kiev: Spirit and letter. Vol. 1 [in Russian].

6. Medushevsky, V. (1980). Man in the mirror of intonation. Soviet music. 1980. No. 9. [in Russian].

7. Osadchaya, S. (2012). Theoretical aspects of the study of the Orthodox singing tradition: history and modernity: monograph. Odessa : Astroprint [in Russian]. 